JPPIPA 7(4) (2021)

\title{
Inventory of Orchid Species and Abiotic Factors in Singkil Swamp Wildlife Sanctuary
}

\author{
Rahmiati $^{*}$, Djufri ${ }^{1}$, Supriatno ${ }^{1}$ \\ ${ }^{1}$ Biology Education, Faculty of Teacher Training, Syiah Kuala University, Banda Aceh, Indonesia.
}

DOI: $\underline{10.29303 / j p p i p a . v 7 i 4.803}$

\section{Article Info}

Received : June 17th, 2021

Revised : August 21st, 2021

Accepted: October 14th, 2021

\begin{abstract}
Rawa Singkil Wildlife Sanctuary currently has various threats such as conversion of forest functions to oil palm plantations, encroachment and other deforestation activities, so this has an impact on the loss of original habitat and ecosystems in it, according to Geographic Information System (GIS) data, encroachment on the Singkil Wildlife Reserve area. reached 4,273 ha. This study aims to inventory orchid species and environmental factors. The method used is a descriptive qualitative approach to identify the orchids found. The results of the inventory found 13 species of orchid species from 9 genera consisting of 5 genera of terrestrial orchids, namely Calanthe, Bromheadia, Arudina, Neuwedia and Eulophia. The 4 genera of epiphytic orchids are Dendrobium, Bulbopyhllum, Papilionanthe and Cymbidium. The species Papilionanthe hookeriana (Rchb.f) Schltr is the most dominant orchid with a relative frequency of $21.27 \%$ and is classified in the low category B class, while the relative frequency of other orchids ranges from $2.12-17.02 \%$ with a very low category. The results of the analysis of environmental conditions $\mathrm{pH}$ ranged from 6-6.8, air humidity $75-80 \%$, soil moisture $27-32$ and air temperature $27-31{ }^{\circ} \mathrm{C}$.
\end{abstract}

Keywords: Orchids, Inventory, Environmental Factors.

Citation: Rahmiati, R., Djufri, D., \& Supriatno, S. (2021). Inventory of Orchid Species and Abiotic Factors in Singkil Swamp Wildlife Sanctuary. Jurnal Penelitian Pendidikan IPA, 7(4), 712-718. doi:https://doi.org/10.29303/jppipa.v7i4.803

\section{Introduction}

Rawa Singkil Wildlife Sanctuary is a nature reserve formed from the Toba eruption about 75,000 years ago. For more than 15,000 years, dense forests grew on sediment and a thick layer of peat, the bottom of which is clay. Due to its geomorphological structure, the Singkil swamp is a mosaic of diverse vegetation types (Anonymous, 2014).

Efforts to save the Rawa Singkil Wildlife Sanctuary have been carried out for a long time, as evidenced by the birth of the Tapaktuan Declaration initiated by Uleebalangs in Gayo, Singkil, South Aceh, and Southeast Aceh to save the Leuser forest, including Rawa Singkil. Efforts to save Rawa Singkil and KEL also involve many parties ranging from indigenous peoples around the forest, local Community Suadaya Institutions, students, researchers, environmental activists, and even involving foreign countries through institutions such as the Leuser Conservation Forum (LCF) and Haka, which focus on forest monitoring and restoration, the Orangutan Information Center (OIC), the Wetland Conservation Society which focuses on monitoring or patrolling with the Natural Resources Conservation Center to prevent and catch forest destroyers, Kfw (Germany) and USAID Lestari which also focus on conserving forests (Anonymous, 2018). This joint effort involving many parties was not enough to stop the rate of forest destruction, especially the conservation area in the Singkil Rawa Wildlife Reserve.

Rawa Singkil is an integral part of the Leuser ecosystem, has diversity, and is an important habitat for various protected animals and plants, including endangered species. This area also supports the life of the surrounding population. Specifically, the Singkil Wildlife Reserve has several natural values, namely rich in flora types, and one of them is orchids.

\footnotetext{
*Email: rahmiati768@gmail.com
} 
Orchid is one of the species that is affected by environmental conditions. Orchids are among the most threatened flowering plants due to over-harvesting, but habitat loss is causing many species to become extinct in the wild. As a result, all orchids are placed in Annex II or higher of the Convention on International Trade in Endangered Species (CITES). Orchids are threatened with extinction due to habitat loss associated with agriculture, urbanization, and over-collection for economic purposes (Cardoso, 2014).

Several studies on orchid diversity have been carried out (Kolanowska, 2014; Vasquez et al., 2003; Zhang et al., 2018). These studies were conducted to determine the diversity of orchid species, which are still widely unknown. The research was conducted to add data on orchid species. However, research on data collection on orchid species and environmental factors has not been done much. Data on orchid species in Aceh Province is still very limited, and there are still many species that have not been identified and their presence, even though in Aceh, there are many protected forest areas that support biological life.

According to the results of observations and interviews with the Banda Aceh Natural Resources Conservation Center and the Singkil Rawa Wildlife Sanctuary, it was found that several orchids were endemic to living in swamps, and there had never been any research on orchids and the importance of preserving orchids in conservation, both in an economic perspective. As well as ecology, research on "Inventory of Orchid Species and Abiotic Factors and Conservation Strategies in Singkil Rawa Wildlife Sanctuary" needs to be done.

\section{Method}

The method in this study uses a survey method by making direct observations at each research station by following the existing path. The approach used in this research is a descriptive qualitative approach and a quantitative approach to describe and identify the orchid species found and measure abiotic environmental factors. This research was conducted in the Rawa Singkil
Wildlife Reserve with an area of approximately $82,326.23 \mathrm{Ha}$. The study is scheduled for nine months, from February 2020 to October 2020. The technique used in data collection is the line transect technique, the type of line transects used the alternating transect type.

The research station was set into three observation stations: the first station in the secondary forest in Rundeng District, Subulussalam. The second station is the primary forest in Kuala Baru District, Aceh Singkil, and the third station is in the swamp forest of Aceh Singkil District. An illustration of this intermittent line transect method can be seen in Figure 1.

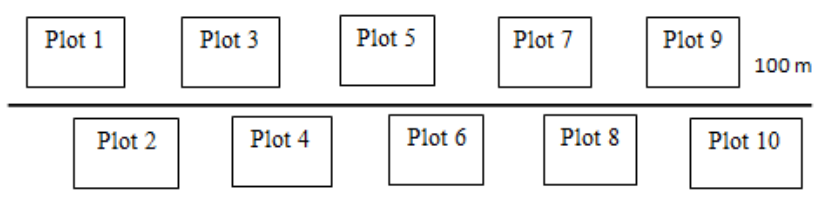

Figure 1. Intersect Line Transect Method

The path that is taken is 100 meters from the first point and follows the path already in the location. During the exploration, the orchids found are documented and labeled A1, A2, and so on. Their abiotic environmental factors are measured and recorded. The data found were identified by looking for the Indonesian name, Latin name, and genus. Then the number of orchids obtained was calculated for Relative Dominance (RD), Presence (FR), and Important Value Index (IVI).

The descriptive qualitative analysis of orchid data was tabulated in the form of tables and figures. In contrast, quantitative analysis is tabulated in the form of tables and graphs.

\section{Result and Discussion}

The results of the analysis of orchid species at several observation stations in the Singkil Wildlife Reserve conservation area found several types of orchids, both epiphytes that live in trees and those that live on the ground (Table 1).

Table 1. Types of Orchids that can be found at the Research location

\begin{tabular}{|c|c|c|c|c|c|}
\hline \multirow{2}{*}{ Code } & \multicolumn{2}{|l|}{ Orchid Species } & \multirow{2}{*}{ Genus } & \multirow{2}{*}{$\begin{array}{l}\text { Number of } \\
\text { Individuals }\end{array}$} & \multirow{2}{*}{$\begin{array}{l}\text { Growing } \\
\text { Traits }\end{array}$} \\
\hline & Domestic Name & Scientific Name & & & \\
\hline$\overline{\mathrm{A} 1}$ & kupu-kupu Orchid & Dendrobium sp. & Dendrobium & 4 & epifit \\
\hline $\mathrm{A} 2$ & bayi sedang tidur Orchid & Calanthe triplicata (Willem.) Ames & Calanthe & 3 & terrestrial \\
\hline A3 & Merpati Orchid & Dendrobium crumenatum Sw. & Dendrobium & 8 & epifit \\
\hline A4 & Bambu Orchid & Bromheadia finlaysonianaI (Lindl.) Miq & Bromheadia & 23 & terrestrial \\
\hline A5 & AGoyang Orchid & Bulbophyllum lobbi Lindl. & Bulbophyllum & 6 & epifit \\
\hline A6 & Bambu Orchid & Arundina graminifolia (D. Don) Hochr & Arudina & 20 & terrestrial \\
\hline A7 & Bambu Orchid & Arundina sp. & Arudina & 5 & terestrial \\
\hline A8 & sp. Orchid & Bulbophyllum macranthum Lindl. & Bulbophyllum & 3 & epifit \\
\hline
\end{tabular}




\begin{tabular}{|c|c|c|c|c|c|}
\hline \multirow{2}{*}{ Code } & \multicolumn{2}{|l|}{ Orchid Species } & \multirow{2}{*}{ Genus } & \multirow{2}{*}{$\begin{array}{l}\text { Number of } \\
\text { Individuals }\end{array}$} & \multirow{2}{*}{$\begin{array}{l}\text { Growing } \\
\text { Traits }\end{array}$} \\
\hline & Domestic Name & Scientific Name & & & \\
\hline$\overline{\mathrm{A} 9}$ & sp. Orchid & Neuwiedia sp & Neuwiedia & 5 & terrestrial \\
\hline A10 & Pensil Orchid & $\begin{array}{l}\text { Papilionanthe hookerianaI (Rchb.f) } \\
\text { Schltr }\end{array}$ & Papilionanthe & 290 & epifit \\
\hline A11 & sp. Orchid & Eulophia spectabilis (Dennst.) Suresh & Eulophia & 2 & terrestrial \\
\hline A12 & Pandan Orchid & Cymbidium sp. & Cymbidium & 4 & epifit \\
\hline A13 & Goyang Orchid & Bulbophyllu sp. & Bulbophyllum & 4 & epifit \\
\hline
\end{tabular}

Based on the data in Table 1, it is known that the number of orchids found at the study site was 13 species consisting of 9 genera of epiphytic and terrestrial orchids. The orchids found showed different absolute dominance and uneven presence.

Table 2. Orchid Distribution Data in Singkil Swamp Wildlife Sanctuary

\begin{tabular}{llllllll}
\hline No & Orchid Species & DM & DR (\%) & FM & FR (\%) & NP & Class \\
\hline 1 & Dendrobium sp. & 4 & 1.02 & 4 & 8.51 & 9.53 & $\mathrm{~A}$ \\
2 & Calanthe triplicata (Willem.) Ames & 3 & 0.76 & 1 & 2.13 & 2.89 & $\mathrm{~A}$ \\
3 & Dendrobium crumenatum Sw. & 8 & 2.03 & 5 & 10.64 & 12.67 & $\mathrm{~A}$ \\
4 & Bromheadia finlaysonianaI (Lindl.) Miq & 23 & 5.84 & 8 & 17.02 & 22.86 & $\mathrm{~A}$ \\
5 & Bulbophyllum lobbi Lindl. & 6 & 1.52 & 2 & 4.26 & 5.78 & $\mathrm{~A}$ \\
6 & Arundina graminifolia & 20 & 5.08 & 5 & 10.64 & 15.71 & $\mathrm{~A}$ \\
& (D. Don) Hochr & & & & \\
7 & Arundina sp. & 5 & 1.27 & 4 & 8.51 & 9.78 & $\mathrm{~A}$ \\
8 & Bulbophyllum macranthum Lindl. & 3 & 0.76 & 1 & 2.13 & 2.89 & $\mathrm{~A}$ \\
9 & Neuwiedia sp & 5 & 1.27 & 3 & 6.38 & 7.65 & $\mathrm{~A}$ \\
10 & Papilionanthe hookerianaI (Rchb.f) Schltr & 290 & 73.60 & 10 & 21.28 & 94.88 & $\mathrm{~B}$ \\
11 & Eulophia spectabilis (Dennst.) Suresh & 2 & 0.51 & 1 & 2.13 & 2.64 & $\mathrm{~A}$ \\
12 & Cymbidium sp. & 4 & 1.02 & 2 & 4.26 & 5.27 & $\mathrm{~A}$ \\
13 & Bulbophyllum sp. & 21 & 5.33 & 1 & 2.13 & 7.46 & $\mathrm{~A}$ \\
14 & Total & 394 & 100 & 47 & 100 & 200
\end{tabular}

The percentage of the presence of orchids in the Singkil Rawa Wildlife Reserve is relatively small compared to other plants. Orchids are plant species that do not have endosperm (food reserves), so germination requires a place containing nutrients for growth. The presence of orchids is also related to various environmental factors that support growth and development in a habitat. The relative frequency of orchids can be presented in Figure 2.

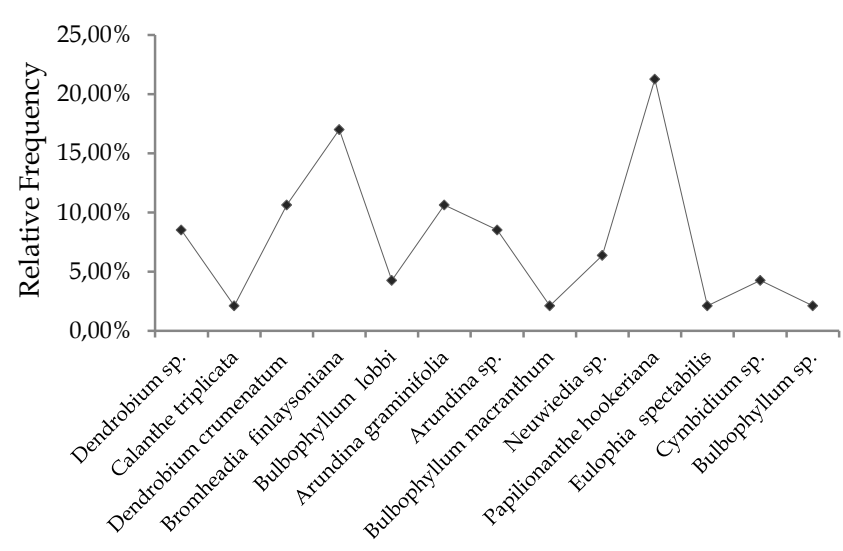

Figure 2. Relative Frequency of Orchids
The relative frequency of a species of organism in a habitat indicates the frequency with which the species is present in that habitat. Based on the frequency of presence can be illustrated the distribution of these species in the habitat. Many or not a type can be seen from the value of its relative frequency (Suin, 2002).

Papilionanthe hookeriana (Rchb.f) Schltr is the most dominant epiphytic orchid among other orchids because the number of individuals is at most 290 individuals with a relative frequency of $21.27 \%$ and is classified into class B (21-40\%) low category lilies that live in swamps (aquatic). Then Bromheadia finlaysiana (Lindl.) Miq was found as many as 23 individuals with a relative frequency of $17.02 \%$ and classified into class A (1-20\%) very low category.

Arudina graminifolia (D.Don) Hochr numbered 20 individuals, had a relative frequency of $10.63 \%$, and was classified into class A with a very low category. Dendrobium cremenatum Sw. with total eight individuals with a relative frequency of $10.63 \%$ who fall into class A very low category. Species Arudina sp. are also classified into class A because the relative frequency is $8.51 \%$, with a very low category because only five individuals can be found. Other species classified into class A are Dendrobium sp. 8.51\%, Bulbophyllum lobbi Lindl. 4.25\%, Neuwedia sp. $6.38 \%$, Cymbidium sp. $4.25 \%$, Bulbophyllum 
sp. $4.25 \%$, Calanthe trilpicata (Willen.) Ames 2.12\%, Bulbophyllum macratum Lindl. 2.12\% and Eulophia spectabilis (Dennst.) Suresh $2.12 \%$ with a very low category.

The high and low-frequency values were caused by the presence of many or few orchids in each study plot. This condition is closely related to the nature of the orchid, namely spreading or grouping and its high population, and related to the number of seeds produced to facilitate the dispersal of seeds by the wind because orchid seeds can spread over hundreds of miles without losing their ability to germinate, and this is supported by appropriate environmental conditions (Sadili, 2013).

Based on the frequency results, the value of the relative frequency of orchids found in the research location is in the low and very low categories. This illustrates that the orchids found in the conservation area of the Rawa Singkil Wildlife Reserve have an uneven and clustered population. Yulia (2010) mentions that the surrounding natural conditions greatly affect its biodiversity, especially natural orchids.

Important Value Index (IVI) is used to determine the dominance of plant species over other plant species. If the important value index of a vegetation type is of high value, then the plant species greatly affect the ecosystem's stability.

The Important Value Index of an orchid provides an overview of its role in the ecosystem and is used to determine the dominance of a species in the community (Figure 3).

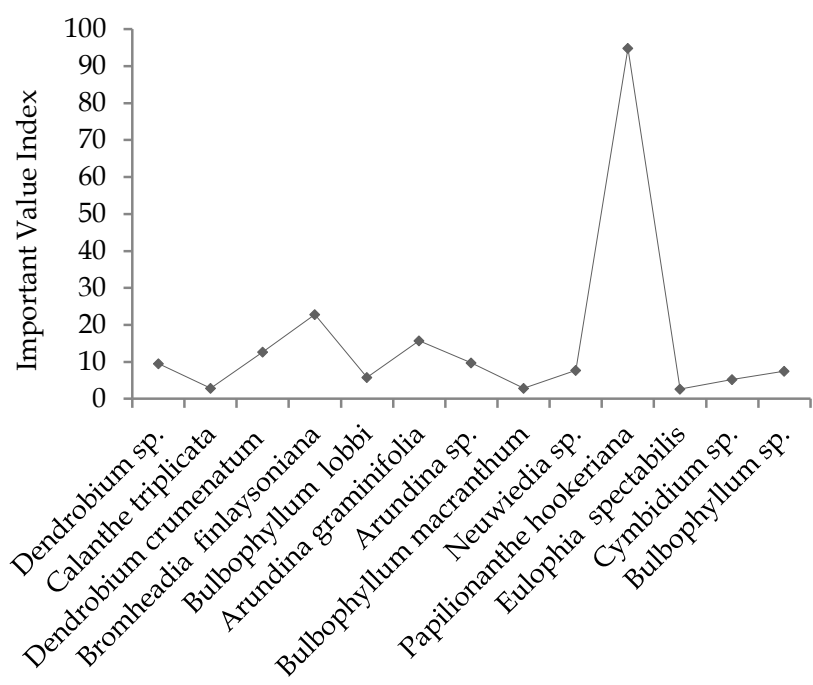

Figure 3. Important Orchid Value Index

The orchid species that has the highest importance value of the 13 types of orchids is Papilionanthe hookeriana (Rchb.f) Schtr which is the highest epiphytic orchid. Its important value index reaches 94.88 , which indicates that this orchid species is the most common orchid found in the Wildlife Sanctuary. Rawa Singkil. The Papilionanthe hookeriana (Rchb. f) Schtr species or better known as the pencil orchid, dominates the swamp ecosystem. With a value of 94.88 , the pencil orchid has a great influence on the stability of the ecosystem.

Orchid species Bulbophyllum finlaysoniana (Lindl.)

Miq, Dendrobium crumenatum Sw. and Arudina graminifolia (D.Don) Hochr are orchids found with an important value index ranging from 22.86-12.67. The value of this important index is lower than that of the pencil orchid. Each of these orchids is in a terrestrial ecosystem which allows its presence and stability to be influenced by environmental factors and other plant populations.

The lowest Important Value Index (IVI) of the orchids found in the Singkil Wildlife Reserve was Dendrobium sp., Calanthe triplicata (willen.) Ames, Bulbophyllum lobbi Lindl., Arudina sp., Bulbophyllum macrathum Lindl., Neuwedia sp., Eulophia spectabilis (Dennst.) Suresh, Cymbidium sp., and Bulbophyllum sp. ranged from 2.64-9.78. This species is not widely found due to low adaptation to the environment.

Orchids are planting whose characteristics lie in the beauty of flowers both in terms of color and flower shape. With the presence of orchids, it is easier to find in a forest friend. However, orchids have various flowering phases, making them more difficult to find. The orchids found in the location were only a few types that were in bloom, making it easier to identify clearly. In contrast, some of the other orchids have not flowered so that they can only be identified until the genus.

\section{Epiphytic Orchid Host Tree in SM Rawa Singkil}

Some of the orchids found at the research site are epiphytic species. Some orchids use trees as perches for upright, growing habitat and food sources. Epiphytic orchid host trees in the study area are presented in Table 3.

Table 3. Epiphytic Orchids and Host Trees

\begin{tabular}{llll}
\hline No & Orchid Species & Host Tree & \\
\cline { 3 - 4 } & Scientific & Domistic \\
\hline 1 & $\begin{array}{l}\text { Dendrobium sp. } \\
\text { Dendrobium } \\
\text { crumenatum Sw. }\end{array}$ & $\begin{array}{l}\text { Gluta renghas } \\
\text { Vitex pubescens }\end{array}$ & $\begin{array}{l}\text { Jingah } \\
\text { Laban (mane) }\end{array}$ \\
3 & $\begin{array}{l}\text { Bulbophyllum sp. } \\
\text { Bulbophyllum lobbi }\end{array}$ & $\begin{array}{l}\text { Nyssa javanica } \\
\text { Eugenia sp. }\end{array}$ & $\begin{array}{l}\text { Medang } \\
\text { Jambu-jambu }\end{array}$ \\
& $\begin{array}{l}\text { Lindl. } \\
\text { Bulbophyllum } \\
\text { macranthum Lindl. }\end{array}$ & Pandanus sp. & Pandan hutan \\
6 & $\begin{array}{l}\text { Papilionanthe } \\
\text { hookeriana (Rchb.f) }\end{array}$ & $\begin{array}{l}\text { Crinum } \\
\text { asiaticum }\end{array}$ & Bakung \\
7 & $\begin{array}{l}\text { Schltr. } \\
\text { Cymbidium sp. }\end{array}$ & Shorea sp. & Meranti \\
\hline
\end{tabular}


The types of epiphytic orchids in the Sigkil Swamp Wildlife Sanctuary have different habitats, namely on the trunk, branches, or on the twigs of tall trees. Generally, epiphytic orchids live attached to a suitable substrate for their survival. Epiphytic orchids get their nutrition from the sucked substrate, especially on the stems or branches, generally on a rough surface (not slippery), but it does not harm the host. Orchids do not have a specific relationship with the host but rather play a role in supporting the microclimate (Puspitaningtyas, 2002).

\section{Orchid Environmental Abiotic Factors in Singkil Swamp Wildlife Sanctuary}

Orchids generally require a maximum temperature of about $28 \mathrm{C}$ and a minimum temperature of around 15 C (Iswanto, 2002). The optimal humidity for orchids is $25 \%-100 \%$ (Aswadi and Aryati, 2015). The range of environmental factors in all orchid observation points was relatively the same. The light intensity ranges from 2500-2910 candela (Cd), pH 6-7.2, humidity 65$85 \%$, soil humidity $27-33$, and air temperature $27-31^{\circ} \mathrm{C}$.

According to Zotz and Schultz (2008), a comprehensive survey of epiphytes in lowland forests has revealed that most species of orchids and individual plants grow in intermediate strata, which means these plants have moderate light requirements. Orchids originating from the tropics or sub-tropics tend to be sensitive to cold temperatures and are difficult to survive if they occur for a long time. High enough temperatures usually support plant growth, but high enough temperatures can interfere with physiological processes.

The results of the analysis show that orchid species have a relationship with various abiotic factors for conditions to grow well.

Based on the correlation test conducted using SPSS between orchid species and all abiotic environmental factors of orchids in the Rawa Singkil Wildlife Reserve, it can be concluded that orchid species are simultaneously related to light intensity, $\mathrm{pH}$, humidity, soil moisture, and temperature factors. The test results of multiple correlation analysis get a correlation coefficient value of 0.8 with a very strong degree of relationship.

The results of the analysis of environmental abiotic factors distribution of orchid species based on habitat, namely Dendrobium crumenatum Sw., Bromheadia finlaysoniana (Lindl.) Miq, Bulbophyllum lobbi Lindl., Neuwiedia sp., Cymbidium sp., and Bulbophyllum sp. are orchids found in two research stations, namely secondary and primary forest. This shows that these six types of orchids can adapt to forests with full and closed light ranging from $2530-2780 \mathrm{Cd}$ with a temperature of $27-31^{\circ} \mathrm{C}$, soil moisture $29-32 \%$, humidity is $69-80 \%$, and the $\mathrm{pH}$ is relatively the same, namely 6-6.9.

Dendrobium sp., Arundina graminifolia (D. Don) Hochr., and Arundina sp., is an orchid that is only able to live in full sun and is only found in the first station, namely secondary forest with air temperatures ranging from $28-29^{\circ} \mathrm{C}$, soil humidity $29-30 \%$, air humidity $78-$ $79 \%$ and $\mathrm{pH}$ ranging from 6-6.3.

Bulbophyllum macranthum Lindl., Calanthe triflicata (Willem.) Ames. and Eulophia spectabilis (Dennst.) Suresh. is an orchid found in primary forest with a light range of $2600 \mathrm{Cd}, \mathrm{pH} \mathrm{6-7,} \mathrm{air} \mathrm{humidity} 65-80 \%$, soil humidity $27-33.4 \%$, and air temperature $27-28^{\circ} \mathrm{C}$.

Papilionanthe hookeriana (Rchb.f) Schltr. Otherwise known as pencil orchids, are orchids that can only be found in swamp forests and are not found in secondary and primary forests. This shows that pencil orchids are influenced by water and full light factors. A tree canopy does not shade this orchid, with air humidity reaching $31^{\circ} \mathrm{C}$ and air humidity $85 \%$.

\section{Economic Value}

Orchids are very diverse flowering plants belonging to the Orchidaceae family. The existence of orchid species in nature is often threatened with increasing uncontrolled exploitation for economic reasons (Nugroho et al., 2018b).

The advantages of orchid plants are determined by color, size, shape, arrangement, the number of flower stalks, stalk length, and durability of flower freshness (Widiastoeti et al., 2016).

Efforts to improve the quality of orchids can be made by genetic improvement efforts through crosses, while increasing the quantity can be done by propagation through in vitro culture. The number of tillers is obtained more in a relatively shorter time. Therefore, orchid breeding is sought to expand genetic diversity in unique shapes and colors, favored by consumers, high flowering frequency, and resistance to disease-causing pathogens and environmental stresses (Hartati et al., 2014).

The overall results of the Singkil Wildlife Reserve's orchids are mostly unique and meet the category or are close to being a leading commodity. Advances in techniques of domestication, hybridization, genetic engineering, products, or products of orchid cultivation with greater quantity and quality are expected to be developed.

Orchid cultivation for business purposes or just a hobby will affect the community's socio-economic life, and planting orchids provides good prospects for the future, especially the types of orchids from crosses.

The demand for orchids, especially in big cities, is currently quite high, with prices quite stable. The popularity of orchids causes this demand among the 
middle to upper-income people and the large number of consumers who need orchids, especially cruciferous orchids, which have the characteristics of large flower sizes, a large number of buds, bright colors, and longlasting. The above success and driven by advances in science and high technology, the orchids in the Rawa Singkil Wildlife Sanctuary are expected to provide better hope for crossbreeds in the future. Apart from being an ornamental plant, orchids also have other functions.

The use of orchids as medicine has long been known since time immemorial, but it is not as popular as its potential as an ornamental plant. Sulastriarini (2008) stated that 53 species of orchids have the potential as drugs from various countries, including Indonesia. Of these 53 species, there are two species in the Singkil Wildlife Reserve, namely Dendrobium crumenatum and Calanthe triplicate. Indonesian natural orchids can be used as a source of food, ingredients for herbal (medicinal) ingredients, perfumes, and raw materials for woven or handicrafts that can add value to the community's economy to develop them for business. The types of orchids in the Singkil Wildlife Reserve really need to be conserved and used wisely, taking into account the correct conservation principles so that the wealth will be sustainable in the future (study, use, and save).

Ecologically, the richness of orchid species in natural forests will be closely related to the wealth of other flora and natural orchid species depending on the condition of the surrounding tree vegetation stands. However, data on the types of orchids found in the research location, namely the Singkil Rawa Wildlife Sanctuary, generally have not been reported as the community's leading economic commodity, especially for sale at ornamental plant stalls.

Species orchids or natural orchids are orchids that can be found in nature and have not been crossed with other orchid plants, these natural orchids can be found in forest areas, topography or other vegetation. Although it is still an orchid that has not been crossed, natural orchids still have beautiful and attractive shapes and colors (Kartohadiprodjo, 2013). Natural orchids have shapes and color variations that are no less interesting when compared to crossbred orchids. Even natural orchids can be used as mother plants for the next cross of orchid species. These attractive variations and colors make orchid plants advantages compared to other plants (Indarto, 2011).

The species of orchid in the Singkil Rawa Wildlife Reserve has so far not been used specifically in any field. Its development is still in the form of growing naturally in its habitat. There is no special development by the conservation manager. Even though there are regulations that protect biodiversity, certain parties still take these species for ornamental plants illegally.

\section{Conclusion}

Based on the discussion that has been described, it can be concluded that there are 13 species of orchids in the Singkil Wildlife Reserve, namely: Dendrobium sp., Dendrobium crumenatum, Bulbophyllum macranthum, Bulbophyllum lobbi, Bulbophyllum sp., Arundina graminifolia, Arundina sp., Papilionanthe hookeriana, Calanthe triplicata, Eulophia spectabilis., Cymbidium sp., Neuwiedia sp., and Bromheadia finlaysoniana. The environmental factors measured were relatively supportive of the growth and development of orchids at the site. Orchids that have medicinal potential found in the Rawa Singkil Wildlife Sanctuary are Dendrobium crumenatum and Calanthe triplicata. The presence of orchids in the Rawa Singkil Wildlife Reserve is relatively rare due to over exploration and habitat destruction caused by environmental damage.

\section{Acknowledgments}

Thank you to my parents, friends in arms and the conservation of natural resources who have provided motivation and support to complete this article.

\section{References}

Anonymous (2014). Rencana Pengelolaan Jangka Panjang Kawasan Suaka Margasatwa Rawa Singkil Kabupaten Aceh Singkil, Kabupaten Aceh Selatan dan Kota Subulussalam Periode 2014 - 2023. Balai Konservasi Sumber Daya Alam Kabupaten Aceh Singkil, Kabupaten Aceh Selatan dan Kota Subulussalam. [Indonesian]

Anonymous (2018). Bersama Menyelamatkan Suaka Margasatwa Rawa Singkil. Serambinews. Retrieved from: http://www.aceh.tribunnews.com/...rawa-singkil. [Indonesian]

Aswadi, S., \& Aryati, E. (2015). Inventarisasi Anggrek di Hutan Adat Kantuk, Sintang, Kalimantan Barat. Semirata, 4(1):624-630. Retrieved from: https://jurnal.untan.ac.id/index.php/semirata2 015/article/view/16392 [Indonesian]

Cardoso, J. (2014). Levantamento de espécies da família Orchidaceae em Botucatu: potencial ornamental e cultivo. Horticultura Brasileira, 32, 7-13. https://doi.org/10.1590/s010205362014000100002.

Hartati, S., Budiyono, A., \& Cahyono, O. (2014). Peningkatan Ragam Genetik Anggrek Dendrobium spp Melaui Hibridisasi Untuk Mendukung Perkembangan Anggrek Di Indonesia. Caraka Tani: Journal of Sustainable Agriculture, 29(2), 101-105. 
doi:http://dx.doi.org/10.20961/carakatani.v29i2 .13394 [Indonesian]

Indarto, N. (2011). Pesona Anggrek Petunjuk Praktis Budi Daya dan Bisnis Anggrek. Yogyakarta: Cahaya Atma Pustaka. [Indonesian]

Iswanto, H. (2001). Anggrek Phalaenopsis. Jakarta: Agro Media Pustaka. [Indonesian]

Kartohadiprodjo, N.S. (2013) Asyiknya Memelihara Anggrek. Jakarta: Gramedia Pustaka Utama. [Indonesian]

Kolanowska, M. (2014). The orchid flora of the Colombian Department of Valle del Cauca. Revista Mexicana de Biodiversidad, 85(2), 445-462. https://doi.org/https://doi.org/10.7550/rmb.3 $\underline{2511}$.

Nugroho, A.S., Rita, E. \& Ulfah, M. (2018). Manajemen Konservasi Anggrek Gunung Ungaran Berbasis Masyarakat sebagai Laboratorium Alam Pembelajaran Biologi Tahun ke-1 dari rencana 3 tahun. Retrieved from: http://eprints.upgris.ac.id/476/1/Laporan\%20L engkap\%20Anggrek.pdf. [Indonesian]

Puspitaningtyas, D.M. (2002). Eksplorasi dan Inventarisasi Anggrek di Kawasan Kebun Raya Bukit Sari, Jambi. BioSMART, 4(2): 55-59. Retrieved from: https://www.semanticscholar.org/paper/Ekspl o...36f9d [Indonesian]

Sadili, A. (2013). Jenis Anggrek (Orchidaceae) di Tau Lumbis, Nunukan, Propinsi Kalimantan Timur sebagai Indikator Terhadap Kondisi Kawasan Hutan. Jurnal Biologi Indonesia, 9 (1): 67-71. doi: https://doi.org/10.14203/jbi.v9i1.147 [Indonesian]

Suin, N.M. (2002). Metode Ekologi. Padang: Universitas Andalas. [Indonesian]

Vasquez, R., Ibisch, P.L. \& Gerkmann, B. (2003). Diversity of Bolivian Orchidaceae-a Challenge for Taxonomic, Floristic and Conservation Research. Organisms Diversity \& Evolution, 3(2): 93-102. doi: https://doi.org/10.1078/1439-6092$\underline{00061}$

Yulia, N.D. (2010). Evaluasi Keragaman Anggrek di Tiga Kawasan Hutan Alam Jawa Timur. UPT Balai Konservasi Tumbuhan Kebun Raya Purwodadi, LIPI, Pasuruan. [Indonesian]

Zhang, S., Yang, Y., Li, J., Qin, J., Zhang, W., Huang, W., \& Hu, H. (2018). Physiological diversity of orchids. Plant diversity, 40(4), 196-208. https://doi.org/10.1016/i.pld.2018.06.003.

Zotz, G., \& Schultz, S. (2008). The Vascular Epiphytes of a Lowland Forest in Panamaspecies Composition and Spatial Structure. Plant Ecology, 195(1), 131141. Retrieved from: http://www.jstor.org/stable/40305456. 